\title{
Learning from community forestry experience: Challenges and lessons from British Columbia
}

\author{
by Ryan Bullock' ${ }^{1}$ Kevin Hanna ${ }^{2}$ and D. Scott Slocombe ${ }^{2}$
}

\begin{abstract}
A multiple case study approach is used to investigate community forest implementation challenges in British Columbia, Canada. Stakeholder interviews, document review and visits to the case sites (Denman Island, Malcolm Island, Cortes Island and Creston) were used to collect data on events occurring between 1990 and 2005. In addition to case-specific challenges, our analysis confirmed common challenges related to a lack of support, consensus, and organizational resources as well as poor forest health and timber profiles, resistance from conventional forest management, and competition for land and tenures. Development pressure emerged as a challenge for communities without land use decisionmaking authority. The final section offers some lessons and recommendations.
\end{abstract}

Key words: community forest, community forestry, forest management, community-based natural resource management, local control, challenges, case studies

\section{RÉSUMÉ}

Une approche détudes de cas multiples est utilisée pour étudier les défis découlant de l'implantation de forêts communautaires en Colombie-Britannique, Canada. Nous avons effectué des entrevues auprès des intervenants, une revue des documents et des visites sur le terrain (Denman Island, Malcolm Island, Cortes Island et Creston) afin de recueillir des données sur les événements survenus entre 1990 et 2005. En plus des défis spécifiques à chaque cas, notre analyse a confirmé des défis communs reliés à la faiblesse des appuis, à un consensus mitigé et un manque de ressources organisationnelles ainsi qu'un mauvais état de santé des forêts et une pauvre répartition de la qualité au niveau des tiges, à la résistance par rapport à l'aménagement forestier conventionnel et à la compétition pour l'utilisation du territoire et la forme de tenure. Les communautés n’ayant pas d'autorité en matière de prise de décision sur l'utilisation du territoire ont connu lémergence de défis face à des pressions de développement. La dernière section présente quelques leçons et recommandations.

Mots clés : forêt communautaire, foresterie communautaire, aménagement forestier, aménagement communautaire des ressources naturelles, contrôle local, défis, études de cas

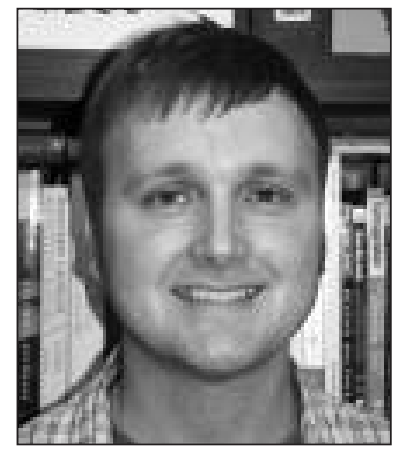

Ryan Bullock

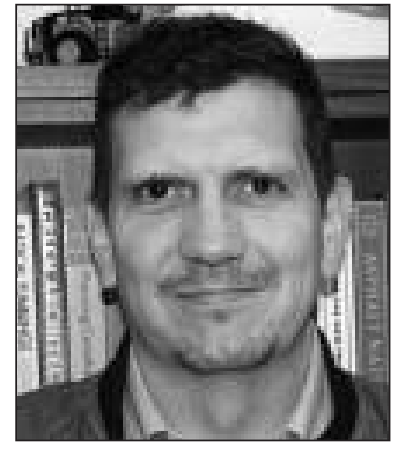

Kevin Hanna

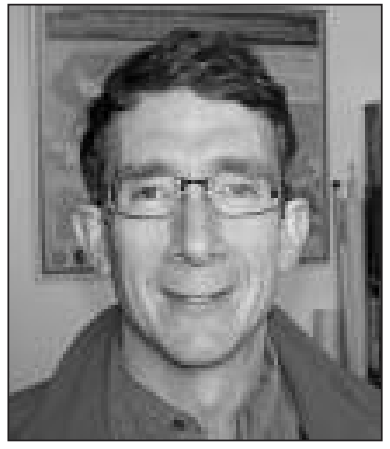

D. Scott Slocombe

tems. It is seen as a way to mitigate conflict over valuable environmental resources and homelands, empower communities, implement ecologicallybased forestry, and restore community links with local environs (Teitelbaum et al. 2006, Bullock and Hanna 2008). Teitelbaum et al. (2006) narrow the most common definitional themes to public lands, direct community decision-making, local benefits, and a working forest to achieve an operational definition. Still, their survey of community forests on public land in Canada makes clear, both conceptually and in practice, that variation across community forests is the rule and not the exception.

Ongoing scholarly interest in community forestry in Canada is furnishing additional insights and empirical evidence to complement concepts examined in key papers dur-

\section{Introduction}

In the broadest of interpretations, community forestry is an alternative forest management approach that provides something for everyone-a collaborative and participatory arrangement of public-private-civic stakeholders, the incorporation of timber and non-timber values, different worldviews, and knowledge into the management of forest ecosys-

\footnotetext{
${ }_{1}^{1}$ Department of Geography and Environmental Management, Faculty of Environment, University of Waterloo, Waterloo, Ontario, N2L 3G1. E-mail: rclbullo@uwaterloo.ca. Corresponding author.

${ }^{2}$ Department of Geography and Environmental Studies, Wilfrid Laurier University, Waterloo, Ontario N2L 3C5.
} 
ing the 1990s (e.g., Duinker et al. 1991, 1994; Allan and Frank 1994; Dunster 1994; Beckley 1998). As implementation has advanced so too has the discussion concerning issues like inclusiveness and representation in policy processes, local decision-making and knowledge production, the potential for and distribution of local benefits, and operational attributes linked to performance and "success" (e.g., Bradshaw 2003, 2007; McCarthy 2006; Reed and McIlveen 2006, 2007; Teitelbaum et al. 2006; Ambus et al. 2007; Bullock 2007; Bullock and Hanna 2008). Not surprisingly, there are several visions for community forestry emanating from the interactions of forestry professionals, researchers, and the public.

This paper presents empirical multi-case study research that illustrates the origins and nuanced interpretations of the community forest concept, elaborating the mix of interests, organizational structures, landbases, and objectives integrated in the local pursuit and practice of community forestry in British Columbia (BC). Contrasting experiences and outcomes are presented with attention to diverse contextual influences. Focusing on events between roughly 1990 and 2005, we investigate critical challenges and motivations for implementing community forestry in $4 \mathrm{BC}$ communities to ground certain perspectives advanced in the literature. The discussion section distils lessons learned from the case studies and literature in order to make recommendations for practice.

\section{Methods}

A multiple case study design was chosen to account for the evolving nature of the implementation process (Fig. 1). It was desirable to find community forest initiatives that had similar origins, management approaches, and a willingness to participate. Practical considerations for data collection led to the focus on southern BC. Four community forest initiatives were ultimately selected-Creston, Cortes Island, Malcolm Island, and Denman Island-each in a different stage (e.g., operational, challenged, and unsuccessful) (Fig. 2) (Table 1). These cases offered a broad range of experience with community forestry. Each has long pursued local control and ecosystembased forest management and each was an active forerunner of the more recent provincial effort to implement community forestry; none was part of the 1998 BC Community Forest Pilot Project.

Data were collected from each case community during June 2005 using site visits and indepth semi-structured interviews (30) with current and past representatives from the community forest organizations, municipal, regional, and provincial governments, First Nations, and industry. This was supplemented by document review (planning and management documents, technical reports, meeting minutes, newspaper articles, Web sites). Transcribed interview data and evidence gathered through sites visits and documents were triangulated and coded (see Yin 2003) based on challenge themes (broadly classed as socio-cultural, institutional, political, resources and information, economic, and biophysical) identified through a review of the community forestry, community-based natural resource management, and implementation literatures.

Detailed case reports were completed and returned to key informants for verification. Analytical generalization and cross-case replication (i.e., similar findings encountered across 2 or more cases) (Yin 2003) were used to identify what we refer to herein as "critical challenges" to community forestry.

Our analysis takes a bottom-up view of implementation (Hjern et al. 1978) as an ongoing, context-dependent and dynamic process influenced by internal and external factors occurring at various scales (Slocombe 1993, Hanna 2007). This view emphasizes the interactions of informal and formal networks of actors and organizations and contextual influences, which are sometimes overlooked, yet instrumental in the initiation and shaping of policy ideas and, ultimately, their success or failure within social and ecological systems (Holling 1995, Berkes and Folke 1998, Olsson et al. 2004).

The case studies focus mostly on events between 1990 and July 2005. Significant events have occurred since, with implications for community forests: there has been a number of new community forest applications, offers, and tenures awarded by the BC Ministry of Forests and Range (MOFR); a 2006 provincial review of community forest policy; a $20 \%$ redistribution of Crown forest lands previously allocated to major tenure holders; and myriad localized site-dependent changes. It is important to be clear on the period covered here given the evolution of community forestry in $\mathrm{BC}$ and the sensitivity of negotiations in some settings. The case studies and results are presented below with a focus on key events, stakeholders, and process challenges.

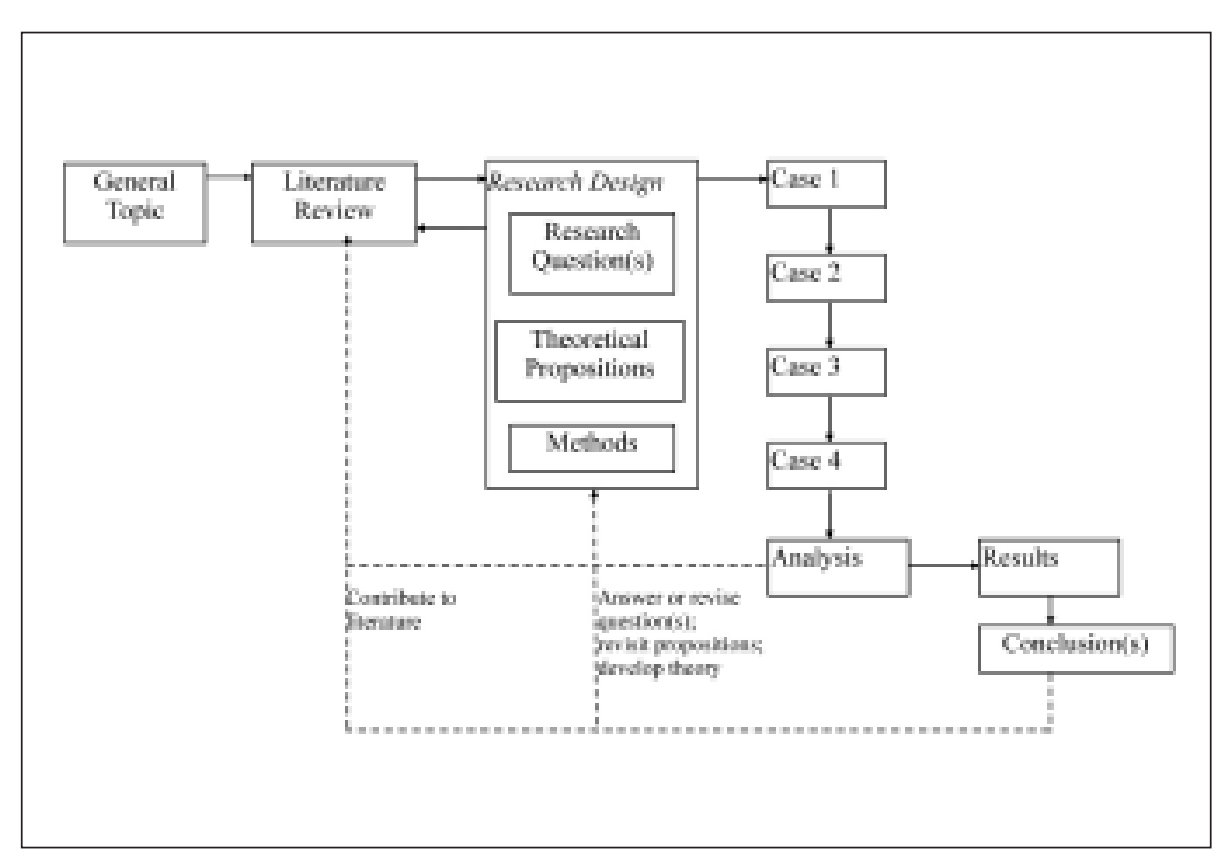

Fig. 1. Multi-case research design for cross-case replication. 


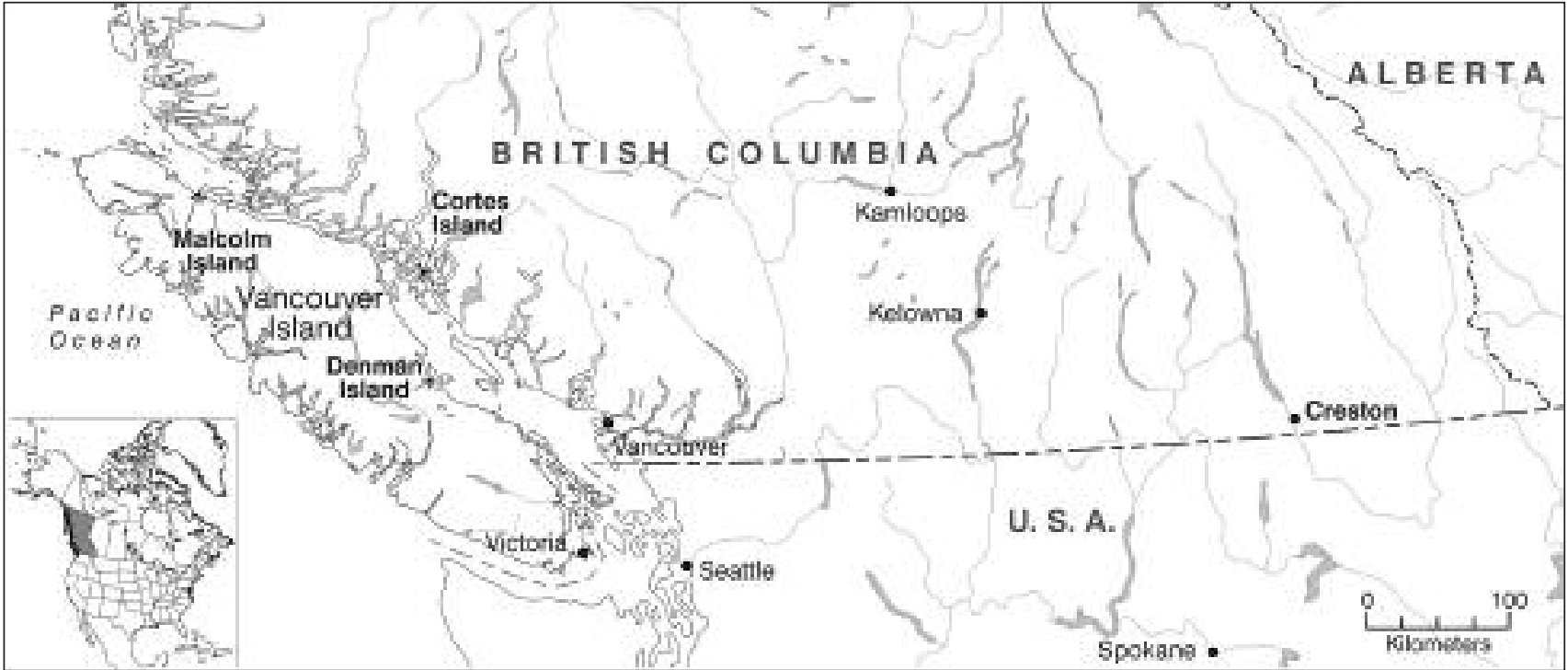

Fig. 2. Case study site locations.

Table 1. Case study attributes

\begin{tabular}{|c|c|c|c|c|}
\hline & $\begin{array}{l}\text { Denman } \\
\text { Island }\end{array}$ & $\begin{array}{l}\text { Malcolm } \\
\text { Island }\end{array}$ & $\begin{array}{l}\text { Cortes } \\
\text { Island }\end{array}$ & Creston \\
\hline Population 2001 & 1250 & 886 & 938 & 4795 \\
\hline Origins of CF movement & Early 1980s & 1990 & Early 1980s & Early 1970s \\
\hline $\begin{array}{l}\text { Landbase size for } \\
\mathrm{CF} / \text { proposed CF }\end{array}$ & $\approx 1700$ ha & $\approx 5000$ ha & $\approx 6500 \mathrm{ha}$ & 12800 ha \\
\hline $\begin{array}{l}\text { Property types involved } \\
\text { in CF/proposed CF }\end{array}$ & Private & $\begin{array}{l}\text { Unallocated } \\
\text { Crown }\end{array}$ & $\begin{array}{c}\text { First Nations, } \\
\text { Private, } \\
\text { Allocated Crown }\end{array}$ & $\begin{array}{l}\text { Unallocated } \\
\text { Crown }\end{array}$ \\
\hline Organizational structure & Co-operative & Corporation & Partnership & Corporation \\
\hline Main industries & $\begin{array}{l}\text { Tourism, } \\
\text { Agriculture, } \\
\text { Services }\end{array}$ & $\begin{array}{l}\text { Forestry, } \\
\text { Fishing }\end{array}$ & $\begin{array}{l}\text { Tourism, } \\
\text { Aquaculture, } \\
\text { Services }\end{array}$ & $\begin{array}{l}\text { Agriculture, } \\
\text { Forestry, Brewing }\end{array}$ \\
\hline
\end{tabular}

\section{Case Studies \\ Denman Island}

Denman Island is one of BC's Gulf Islands, located in the Straight of Georgia between Vancouver Island and the western coast of BC. The cover is mainly second-growth Douglasfir-dominated forests with isolated small patches of mature forest. Dryer portions of the Coastal Western hemlock zone are also found, often in areas with bedrock close to the surface. Conditions for farming are quite favourable in some areas.

The island is almost entirely privately owned (93\%), save for some Crown park lands and there are no First Nations reserves. It is largely a settled landscape. Located within the Regional District of Comox-Strathcona, Denman Island does not have municipal status but is organized under the Island's Trust Council, which administers community planning needs (zoning and by-laws, services, environmental protection). Like other Gulf Islands, Denman Island is a summer haven for urban dwellers and tourists and in recent years there has been an influx of retirees. Agriculture, forestry, and fishing were once important; however, the majority of Denman Island residents now work in health and education, government, business and management, services, and manufacturing (Statistics Canada 2001). There is a vibrant tourism industry. Denman Island is not a "blue-collar" rural resource community, and it does not depend on forestry.

The drive for increased control of forest resources on Denman Island began in May 1995 when long-term landowners Weldwood of Canada Ltd. sold nearly $1 / 3$ of the island to John Hancock Timber Resources Group, a Boston-based firm. With no government on the island, the Denman Forestry Committee (DFC) had long monitored infrequent harvesting activities and residents used the property as "public" green space. The new owners planned to increase harvesting, which greatly concerned residents. A public meeting found consensus for forest conservation, but 3 paths of action would be pursued simultaneously by separate groups: 1) continue monitoring Hancock's harvesting processes; 2) buy the land from Hancock, and; 3) comanage the lands with Hancock in order to influence practices. Hancock indicated a willingness to work with the community. The "buy-out group" became the Denman Forestry Initiative (DFI) when funding was secured from Forest Renewal BC (FRBC) (Beattie 1997), and Silva Forestry Consultants were commissioned to conduct long-awaited 
ecosystem-based planning and landscape assessments. Ongoing resident protests stalled Hancock's operations. Then, in what seemed a sudden turn of events, Hancock announced the sale of their Denman Island holdings to 4064 Ltd., a BC company.

This sudden change of ownership and subsequent accelerated harvesting set off a rapid course of events with negative consequences for community management goals. Denman Island erupted into daily protests, work interruptions, and heated personal disputes between loggers and residents. Some 200 residents attended an emergency meeting and expressed unanimous support for the purchase and management of 4064's local properties. The community also met with the BC Premier, officials of MOFR and FRBC in July 1997 to seek support (DCFC 2001). The Premier appeared supportive but pressed the community to develop a credible business plan. The working business plan included objectives for timber harvesting, residential land development, ecoforestry education, fundraising for conservation, and an investment program for community ownership of forest resources.

DFI met with 4064 Ltd. on July 23, 1997 (DCFC 2001). The company shared its own forest inventory data with DFI, who became aware for the first time that detailed information did actually exist; previous owners had never provided such data. 4064 Ltd. agreed to community monitoring and to hold off on harvesting until August 1997 to enable preparation of a purchase offer. Meanwhile, public meetings, blockades, and a protest at the $\mathrm{BC}$ Legislature were staged and sustainable forestry by-laws were being developed and pushed through with support from the Islands Trust. A cash offer of $\$ 16.5$ million was made to 4064 Ltd. in late August 1997, which was rejected as being too low; $4064 \mathrm{Ltd}$. partners involved in log trading and sawmilling also had prearranged timber interests (Beattie 1997).

Formation of the Denman Community Forest Co-operative (DCFC), completion of the Ecosystem-based Landscape Analysis and Plan from Silva Forestry Consultants, and formal strategic meetings to establish long-term goals, prioritize activities, and determine a clear vision came too late-nearly 3 years after Hancock's controversial purchase. By this time harvesting was well underway and the proposed landbase had been considerably reduced. Talks with $4064 \mathrm{Ltd}$. were halted due to the perceived futility of the process (DCFC 2001).

In May of 1999, Sustainable Forest Land Use by-laws came into effect (DCFC 2001). By spring 2006, 4064's Denman Island properties were in the process of being sold to a number of new owners. Residents were considering a new, controversial development proposal for a large part of the formally proposed community forest lands, which would add several new homes in the most scenic areas, with a small portion of land earmarked for a community forest or public green space. The prospect of having a successful community forest seems doubtful given the small size and degraded nature of the landbase.

\section{Malcolm Island}

Malcolm Island is located $5 \mathrm{~km}$ off the northeast coast of Vancouver Island. The majority of the island is uninhabited Crown land, interspersed with some private holdings, and the largely uninhabited Malcolm Island Indian Reserve 8, which belongs to the 'Namgis Nation of nearby Cormorant Island. The island is part of the Regional District of Mount Wadding- ton (RDMW), a vast, sparsely populated forestry and mining hinterland. As an unorganized territory, Malcolm Island is represented by one seat on the RDMW board, and residents elect a small group of representatives to advise local planning processes.

The Island has been extensively harvested and the current cover is predominantly second growth and plantations. Also found are wet forests with coastal bogs, with forests tending to cedar-salal types, except in well-drained areas where more typical Western hemlock and Amabilis fir forests can develop.

Malcolm Island has experienced significant economic downturn in the last decade linked to depleted natural resources, changing policies and markets in the fishing and forestry sectors (RDMW 2005). Currently, about $18 \%$ of the island's forest cover is merchantable timber, and $50 \%$ of that is protected under the provincial Old Growth Management Area strategy. From 1996 to 2001, population decreased by $16 \%$ and the unemployment rate increased to $17.2 \%$ (Statistics Canada 2001). These factors indicate a rural forest and fishing resource economy in the final stage of the "resource cycle" (Clapp 1998).

The idea for a community forest came shortly after Interfor left the island in 1989 and the Crown forest lands reverted to provincial control. A co-operative approach was assumed to ensure that the future community forest would be controlled by and for the community. By 1994 the idea had regional government support and the Malcolm Island Community Forest Feasibility Study was commissioned under the auspices of the RDMW and completed in 1996. The report reflected residents' perceptions of 3 key advantages of community forestry: 1) local control; 2) local economic benefits and employment, and; 3) diversified use of forest resources. An ecosystem-based approach for preserving and restoring biodiversity was adopted. The report suggested 2 tenure options that would be suitable for developing a community forest: 1) acquire control through a Crown land grant, or; 2) the creation of a new tenure form for community management. While Malcolm Island's proposal was considered innovative (M'Gonigle 1996) among several BC communities striving for local control, there was no supporting legislation, formal application process, or provincial support for the idea.

The community was interested in obtaining control of nearly the entire island. On-island Crown land woodlot operators were not pleased and some residents were sceptical. A proposal and expression of interest were sent to MOFR during the spring of 1997, but this request was declined directly by the Forest Minister. After years of generating data, community meetings, planning, and lobbying, local support dissolved. Ironically, just a short time later in October 1997 the Minister of Forests announced the Community Forest Pilot Project. Subsequent legislation was passed to implement community forests during July of 1998. The province received 27 community forest applications in 1999, but Malcolm Island was not represented due to low community support and timing.

Five years later, MOFR plans to allocate additional woodlot licences on Malcolm Island caused a resurgence of local interest. By 2002, some of the original community forest supporters and others reformed as the Malcolm Island Community Forest Initiative (MICFI) and a mail-out survey reaffirmed wider community support. Again supported by the RDMW, MICFI members visited existing BC community 
forests (e.g., Revelstoke, Mission, Creston) to assess options and local experience. MICFI believed that a non-profit corporate model (after Creston) would streamline decision-making, ensure fair representation, and return full benefits to the community. With legal advice, some well-known stakeholders were selected to represent diverse local values: 1) Broughton Archipelago Stewardship Society; 2) Sointula Recreation Association; 3) Malcolm Island Lion's Club, and; 4) Malcolm Island Resource and Development Society. The new mandate, goals, and objectives were decidedly less preservationist and a much smaller portion of the island was identified.

The Malcolm Island Community Forest Corporation (MICFC) was formalized in October 2004 (Broughton Archipelago Stewardship Society 2004). The group had been actively lobbying various governments including the MOFR, RDMW, and 'Namgis First Nations and they had received expressed support from the North Island Minister of Legislative Assembly. A brief "proposal" with no business plan was again sent to the District MOFR but by this time the formal provincial process was in place for implementing community forests through Community Forest Agreements. The community was informed that it was the Forest Minister's call to invite applications from community groups and that no such invitation had been made. Poor timber age class distribution was also cited as a reason to limit new allocations on Malcolm Island to woodlot tenures. Support for community forestry waned and volunteer energy reached its limit; the second thrust to form a community forest on Malcolm Island was unsuccessful, though interest remains.

\section{Cortes Island}

Located at the entrance to Desolation Sound in the Straight of Georgia, Cortes Island is the northernmost Gulf Island. Much of the central island contains rocky hills and well-drained basins of productive forest land. Cortes is dominated by second-growth Douglas-fir. Some pockets of older-mature forest are found among small patches of old-growth.

MacMillan Bloedel (MB) began to purchase prime lands from homesteading families in the 1950s. As a result, corporate interests own a good portion of the best lands, and 14\% of Cortes Island. A large portion of the island is Crown land (39\%) and government protected areas (10\%), while another $34 \%$ rests in a number of small private holdings (Silva Forest Foundation 1996). The remaining $3 \%$ is reserve land for the Klahoose First Nation, which has outstanding land claims on the island. Cortes Island is a distinct electoral district with one representative on the Regional District of Comox Strathcona board, which provides more autonomy than many other small unorganized communities.

An inflow of newcomers and residential development is an issue for community members who want to sustain forest lands and maintain local culture. From 1995 to 2001 the island's population increased 6\% to 938 (Statistics Canada 2001). Seasonal residents and tourists pour in during the summer months. Recent socio-demographic profiles reveal a highly educated adult citizenry who are employed mainly in professional and service industries (Statistics Canada 2001). Just under half of the total population is between the ages of 35 and 64 and more than $40 \%$ of them have a university education, while an additional $29 \%$ have a college education or trade certificate. While forestry is not a main economic driver, about 55 craftspeople, artisans, builders, and labourers are linked to local forestry and forest value-added (personal communication, Cortes Ecoforestry Society, February 2006).

The Cortes Island Forestry Committee (CIFC) was formed in 1988 over concerns for resumed industrial harvesting on the island. These concerns peaked in 1990 when nonaboriginal residents joined a Klahoose-led protest against MB's plan to resume harvesting on lands adjacent to the Klahoose village. With an interest in defending their public image, $\mathrm{MB}$ agreed to stop logging on the island until a plan could be developed that would satisfy community interests. A CIFC survey found that $86 \%(n=300)$ of the non-aboriginal community wanted to maintain forest integrity as a primary value (CES n.d.). The CIFC commissioned Silva Forestry Consultants in 1992 to create the Cortes Island Forest Plan; the idea actually came from Klahoose who were a previous client. MB returned in 1993 with a partial cutting plan that was reluctantly accepted by CIFC and logging resumed for 5 years until 1998 (Klahoose, CES and Weyerhaeuser 2000).

At the same time, island residents were alarmed by 2 pivotal events during the winter of 1998-1999: 1) without notice, MB sold 2 land parcels to a private logging company (4064 Ltd.) and;2) the Minister of Forests allocated the Crown lands on Cortes to Canadian Forest Products without the legally required consultation of Klahoose or community involvement (Klahoose, CES and Weyerhaeuser 2000). These events solidified desires for local control, and the Cortes Ecoforestry Society (CES) was formed to provide official representation for non-aboriginal residents.

Parallel proposals by Klahoose and CES to purchase various $\mathrm{MB}$ properties gained the attention of MB's environmental vice president responsible for negotiations in Clayoquot Sound and the Great Bear Rainforest. Realizing the difficulty of raising \$15 million to buy MB's land, Klahoose and CES approached the provincial government for ideas. Weyerhaeuser purchased MB in fall 1999, but they were bound by provincial conditions to maintain good faith negotiations with Klahoose and CES and negotiations continued (CES n.d.).

At the same time, Klahoose and CES learned of BC's new Community Forest Pilot Project and so CES began preparing a proposal. The working arrangement between the Klahoose and non-aboriginal residents resulted in the signing of a Memorandum of Understanding in July of 1999. At the same time negotiations between Klahoose, CES and Weyerhaeuser led to an innovative 3-way proposal meant to settle the Cortes land use conflict. The Cortes Initiative proposed to convert Weyerhaeuser's Cortes lands to Crown status in exchange for Crown lands elsewhere to enable the formation of a community forest on new and existing Cortes Crown land (Klahoose, CES and Weyerhaeuser 2000). The proposal was presented to the provincial government in May 2000, but was turned down by the Minister of Forests on the basis that Weyerhaeuser wanted too much compensation for its lands and that there were unresolved traditional boundary issues between Klahoose and a neighbouring First Nation. The community felt this was a hollow rejection as the boundary issue had, in fact, been resolved between the 2 First Nations. Moreover, the proposal had solid First Nations, non-aboriginal, and industry support, a partnership structure, business plan, and management plan complete with maps. 
Klahoose tried to repackage The Cortes Initiative as a Treaty Interim Measure. With support from the Premier, MOFR bureaucrats in Victoria were directed to advance the process. In March 2001, a framework agreement was finally signed by Klahoose, and the provincial and federal governments (CES n.d.). After a decade of protest, planning, and negotiations it appeared that a community forest would finally become a reality on Cortes Island. However, about 2 weeks after the Treaty Interim Measure was signed a provincial election was called and the agreement was dropped. During the spring of 2001, CES also lost Klahoose support with the parallel election of a new Chief and Council with different priorities. Without Klahoose and government support, there was little chance for a CES-run community forest. In spring of 2006 the election of a new Klahoose Chief and Council was rekindling optimism for a Klahoose-CES community forest.

\section{Creston}

Creston is located in the southeastern part of British Columbia in the scenic Kootenay River Valley, which is bounded by the Selkirk and Purcell Mountains. The "flats" are partially drained wetlands that provide high quality agricultural lands. The west side of Kootenay River is willow- and sedge-dominated wetlands subject to inundation. The lower-elevation uplands support Douglas-fir and western larch forests, and are mostly second growth. Originally a fire-maintained ecosystem, the Creston area is one of the drier variants of the Interior Cedar-Hemlock zone.

The Creston Valley Forest Corporation (CVFC) was the result of over 20 years of heated conflict between residents, water users, and forest companies over ongoing pressure to harvest the 8500-hectare Arrow Creek watershed. Years of Public Advisory Committees and regional land use planning efforts (i.e., Commission on Resources and Environment) passed yet Creston residents failed to have Arrow Creek protected. In response to the closure of Creston's Crestbrook Forest Products in 1990, a diverse resident lobby group was formed to express concern for local economic and environmental issues. Local lobbying persuaded government and the local Minister of Legislative Assembly to consider community tenure to mitigate conflict and permit local control of watershed management. The MOFR invited Creston to apply for an upcoming Forest Licence and 2 proposals were submitted: one from the Town and 2 sawmills, and one from the group of other local stakeholders-though the Town soon changed sides.

In June 1997 the Forest License offer was announced and the CVFC was formalized. Five shareholders were represented: Town of Creston, The Regional District of Central Kootenay, The Lower Kootenay Indian Band, The East Kootenay Environmental Society, and The Creston Area Economic Development Society. A local bank provided a \$280 000 start-up loan. A 15-year, volume-based, non-replaceable Forest Licence was awarded in October 1997. About 93\% of CVFC's 12 800-hectare operating area was highly significant to community water supplies.

Residents continually expressed their uneasiness over CVFC's potential logging in Arrow Creek. Also, the local mills felt they were not supported locally and that they were losing access to a local wood supply. A public meeting in September 1999 raised the issue that preservation in Arrow
Creek had previously failed and that it was not a reasonable option. CVFC planned to log some winter-damaged stands in Arrow Creek and obtained a cutting permit that included one cutblock in Arrow Creek. Partial cutting techniques were used throughout to demonstrate their application and earn community trust, but it was still a very contentious exercise. Reconnaissance also revealed that much of the operating area had been heavily cutover and burned several times. Not surprisingly, Arrow Creek had the best standing timber because it had long been protected.

CVFC then concentrated on doing partial cutting outside of Arrow Creek to build community trust, and they eventually satisfied several water advocacy groups-Water Action Network, Erickson Improvement District, and Erickson Water Users Society. However, the operation struggled financially. A newly formed and unprofitable log sort yard, excessive stumpage rates, poor access to markets, and low log prices minimized potential profits. In 2002, Silva Forest Consultants were hired to develop an ecosystem-based plan to address fire interface responsibilities. This project supported CVFC's green goals and objectives but added costs that were not recognized by the provincial stumpage appraisal system. In February 2003, a corporate manager was added to assist the forest manager.

By spring of 2006 CVFC was working to convert its current tenure to a long-term Community Forest Agreement with an expanded operating area. Discussion with industry and government was ongoing while First Nations support was withdrawn. It seems that expansion cannot come too soon as the Forest Revitalization Plan land redistribution and newly formed protected areas for caribou habitat have put pressure on local land availability. Adapting to ongoing challenges, CVFC has supported local control, collaboration, public participation, ecosystem-based forestry, local economic development, and water conservation in a sensitive and controversial local watershed.

\section{Discussion}

While each community experienced context-specific challenges and events, a multiple case study design enabled identification of common challenges for the cases examined (Yin 2003). Critical challenges are discussed in the following section.

\section{Low local support and awareness}

The case studies show that garnering and maintaining local support is a persistent challenge. Communities are seldom homogeneous. There is usually a small group of community forest proponents, a small group of opponents, and a large group of passive potential supporters/detractors who can be persuaded, but whose support shifts over time as different issues and events emerge. Demonstrating forward progress to the community is essential to maintaining wider support. But this was very difficult in all cases given the long proposal development process, slow response times in negotiations with government and industry, and limitations of volunteer power and capabilities.

Local support for community forestry presupposes awareness for the concept. Here we see that community support tends to increase as residents learn more about community forestry. As shown here community-orchestrated surveys are 
often used to gauge local public support and awareness; however, further academic research should try to gauge regional awareness for community forestry and ecosystem-based management. We know that industry and government represent values that can be very different from those of the public, in spite of public opinion surveys that highlight public desires (Robinson et al. 2001). Increasing awareness of community forestry could mobilize that mass of potential supporters and help to increase overall success. The BC Community Forest Association (BCCFA) is contributing to this. Interested communities should support community forestry by supporting one another through involvement with associations and forums in order to strengthen community networks, resources, and the collective voice of community forestry. A prime example might be the need for the MICFC to join BCCFA to bolster their lobbying efforts.

\section{Difficulty reaching consensus}

It is somewhat ironic that community forest initiatives seek to resolve conflict by introducing collaborative management and mechanisms for public involvement in forest management. In some settings, multiple stakeholder involvement can create conflict and complicate management (Bullock and Hanna 2008). The diversity that typifies most communities usually necessitates a long period of negotiation and communication to inform those directly and indirectly involved and to reach agreement on goals and objectives. The process of generating consensus is, therefore, time-sensitive. This was a key issue on Denman and Cortes Island where constant and sudden change required swift community action. Yet initiatives that try to move forward before reaching consensus will face further conflict or failure. Denman Island residents pursued several courses of action, which effectively fragmented the community vision and already limited resources.

The case studies revealed a preference for corporate management models in order to streamline decision-making-a difficulty with non-profit societies and co-operative models. The case studies also show that communities would benefit from guidance on how to structure decision-making processes. Guidebooks and other resources are being created to assist communities (see Gunter 2004, BCCFA Web site ${ }^{3}$ ) and, short of providing funding, the provincial government could play a key technical role.

\section{Lack of human and physical resources}

Some communities are naturally endowed with diverse human and physical resources. Cortes Island is a good example of what can be achieved by aboriginal and non-aboriginal groups where there is strong leadership, financial backing, and a well-informed and educated citizenry. Still, it is more likely that communities will have incomplete skill sets at their disposal and will require professional consultation and, ultimately, money. This research found that lack of access to funding, people with forestry and business training, and a strong volunteer network were critical challenges for community forest initiatives. CVFC was long troubled by the large initial debt and business management challenges. The 3 island communities spent significant amounts of money on

${ }^{3}$ http://www.bccfa.ca/publications.php plans that were never realized. The perceived need for significant external funding for community forests in the start-up phase is not new (Duinker et al. 1994).

The FRBC grants once available to resource communities for community forest feasibility studies are no longer. Short of providing funding to community forest organizations, senior government could help to build local capacity through management training and technical support. But the experiences documented here show that the MOFR has shown variable commitment to play a supportive technical role and there has been debate within the Forest Service about how much community "hand-holding" should occur. For example, while the Kootenay Lake District MOFR has shown strong support for community forestry, MOFR representatives stated that community forests do not receive special attention and are "handled as any other licensee." Some see this as a larger cultural obstacle with respect to the Forest Service-a certain resistance to policy innovation, especially when it threatens longestablished agency-industrial client relationships. To be fair, MOFR resources were also scaled back significantly, and so local and provincial resource constraints can be seen as related (Parfitt and Garner 2004).

Organizational resource challenges cannot be solved without recognizing that community forest implementation involves significant individual and social learning. While learning is a rising theme in several allied literatures (e.g., public participation, collaborative management and planning, adaptive co-management) pertaining to resource and environmental management (e.g., Daniels and Walker 1996, Schusler et al. 2003, Olsson et al. 2004, Keen et al. 2005) Canadian community forest scholars have given it little attention to date. The case studies showed that community forest organizations can be very adaptive in dealing with rapid change and uncertainty. However, there is a need to study learning in these organizations, and the community at large, as a prerequisite to building adaptive capacity and improving their success.

\section{Poor forest health and timber profiles}

The optimal forest for community forestry would be diverse in terms of tree species and age class, have ample good quality timber, a variety of landforms, and good site quality in terms its soils and productivity (Duinker et al. 1991, Matakala and Duinker 1993, Allan and Frank 1994). However, forest lands of this sort are increasingly difficult to find near communities. Certain industrial harvesting practices lead to a considerable loss of trees and diverse conditions created by the trees (Kimmins 1992). Rural forest resources have, in some instances, been severely degraded by highgrading and inadequate regeneration (Duinker et al. 1991), which requires significant rehabilitation to create the kind of forest conditions necessary for a healthy forest and viable community forest. Community forests composed of such lands will be dealing with a forest uniform in age and species composition for a number of years (Duinker et al. 1994).

Poor forest health and timber profiles are ecological challenges with negative implications for planning and operational viability (Duinker et al. 1994). This was a critical challenge for all island communities in developing viable business plans as well as for Creston's operations and financial longevity. As a business, a community forest requires a sufficient supply of good-quality timber. The ecosystem-based 
management principles employed by many community forest organizations are suited to restore forest health but this will require initial sacrifice to do so. Due to depleted timber stocks and concerns for forest health, communities often plan to protect much of the best standing timber and productive sites. In the meantime community forest organizations need to make money.

There is a need for community forest research that explores the potential for non-timber forest products to alleviate timber dependence and diversify local economies. First Nations in particular should have an active role in this. While community forest supporters express the intention to diversify forest utilization and products, practical examples are few (e.g., Harrop-Proctor ${ }^{4}$ ). There is a need for research on the potential of non-timber forest products; it is an area that is often talked about but rarely realized.

\section{Weak senior government support}

The communities under study were pursuing control over local forest resources long before they could be considered outliers of any provincial process. Each was part of the early BC movement for local control. In many ways community forest policy originated at the grassroots level and provincial government support has been slow to develop. Now that provincial support has increased and a formally controlled, structured application process is in place, some communities face the paradox of not fitting into the new provincial framework. The province appears to have assumed a gatekeeper role, rather than that of guide or facilitator. In this way participatory approaches can reproduce rather than reverse or subvert uneven government-community power relations in that the opportunity and process model provided for involvement are no longer "local" (Quaghebeur et al. 2004). Senior BC government remains hesitant to devolve power over resources to local organizations and settle into a support role; though ironically, they are pursuing policies that would see large firms self-regulate/self-monitor their use of public forest lands. Though all 4 cases here had apparent support from Ministers of Legislative Assembly or other provincial politicians, and all had regional government support, only one (Creston) became operational. True government support is accompanied by vital resources and authority.

By maintaining top-down control, it can be argued that provincial co-optation has added additional barriers. As one MOFR District Manager pointed out, the application requirements for communities exceed what is required of many other industrial tenure holders. Communities must satisfy provincial application requirements, including detailed plans and studies that are expensive in terms of time and money, which can exacerbate future operational problems and there are no guarantees. Another MOFR representative commented that highly organized and well-planned local initiatives to obtain a community forest tenure could fail due to provincial objectives and timber availability while other hasty and loosely organized initiatives could obtain a tenure based on economic need and political will at the provincial level.

While MOFR representatives maintain that community forests are "just like any other tenure" there is clearly a double

\footnotetext{
${ }^{4}$ http://www.hpcommunityforest.org/
}

standard for industry and communities. Participants from each locale perceived the MOFR as an old-line institution with strong ties to industry that is characterized by power differentials between district, regional, and central offices, which impedes community efforts. Conversely, a common sentiment among MOFR representatives was that community forest organizers were often too idealistic and "green" and that local plans for community forestry needed to be more realistic to win senior government support. Reconciliation of these diverse perceptions and the conditions creating them is needed to build and maintain a positive rapport to foster community forest policy-making and implementation.

\section{Resistance from conventional forest management paradigm}

The question of government support is intertwined with challenges produced by contrasting paradigms (Beckley 1998). Community forestry has been developed locally for different reasons and on different foundations than was sustained yield forestry. Small-scale, multi-valued, ecosystem-based forest management contrasts with the values and practices of senior government, professional (technical) forestry schools, and industry that have long controlled forestry in BC. Presently, neither realm is really satisfied. These case studies illustrate that there are clear value differences between communities and industry that do not facilitate negotiations. Community demands based on the tenets of ecosystem-based forest management may have seemed unreasonable to companies that were used to more conventional forest management approaches. One forester was critical that technical forestry training emphasizes timber volume as the default variable at the expense of all other values.

Moreover, there are conflicting views of community forestry and its intended management role. As seen here, many communities perceive community forests as a grassroots, conservation-oriented, and "green" approach to local economic development, while government intends it to be a simple economic development opportunity that can be administered like any other tenure. It can be expected that government will continue to move community forest management towards a model that suits its own vision and needs. A problem in $\mathrm{BC}$ is that public policy is subject to significant ideological shifts (Bullock and Hanna 2008). The current provincial framework pulls community forestry towards an industrial model. Many communities, along with the BCCFA, have struggled for more flexible community forest policies to support local goals and objectives.

As seen here, many community forests began with a strong ecological orientation and then became increasingly aware of forest economics with time. Some government and community representatives attribute this to a "reality check" that comes with basic business management priorities. In other ways, it reflects a compromise of values as community forests must try to fit into an industrial framework of ill-suited policy designed by professionals from a conventional forestry tradition-a tradition that may no longer be capable of managing complex social-ecological systems characterized by conflict, uncertainty, and rapid change.

\section{Competition}

Competition for forest land and tenures is great due to land claims and the $20 \%$ timber reallocation in BC. This is espe- 
cially true when there are First Nations locally who could be potential stakeholders in a community forest, but might also be looking to do something on their own as part of an eventual land claim. First Nations support was a pivotal factor for community forest efforts on Cortes Island and in Creston, and Malcolm Island had approached the 'Namgis Chief and Council to discuss possibilities. However, as seen here there may be other pressing commitments and issues that First Nations communities choose to address ahead of involvement in a community forest. The rising influence and variability of First Nations as important players in BC forest management could prove to increase uncertainty for nonaboriginal communities that seek forest tenures.

The logistics of timber reallocation will figure into MOFR calculations and, therefore, community forest opportunities. Regional AAC allotments affect redistribution, so if there are several First Nations, communities, and existing licence holders with interest in a particular region (e.g., Malcolm Island, Cortes Island, Creston), it could be much more difficult to get a community forest tenure or expanded operating area. Competition for private land is a background force that represents a critical challenge, especially for communities where development pressure and population growth are a concern. Private competition can diminish the landbase available for community forestry in places where finite land resources exist within and around communities, and where community funds do not permit head-on purchase competition with big business. Denman and Cortes Islands are good examples of this dynamic.

\section{Unsupportive stumpage appraisal system}

Creston was the only case study to advance to a stage where stumpage fees were applicable; however, the importance of stumpage policy as a challenge to Creston operations warrants mention here, and future attention. Community forests that practise ecosystem-based management in their operations have faced very high stumpage fees (e.g., $\$ 40$ per $\mathrm{m}^{3}$ ) because some choose alternative management practices (e.g., partial cutting, less road-building) that do not figure into the provincial stumpage framework. In response to stumpage and other challenges CVFC and CES worked with other community forest organizations in forming the BCCFA in 2002. The group has tried to change the stumpage appraisal system by developing alternative ideas regarding stumpage and by lobbying government. A main goal is to design an appraisal system that will account for forestry practices that consider wider forest values and provide beneficial services (e.g., water and soils, viewscapes and aesthetics, wildlife habitat protection, fire interface). The province and BCCFA are working together to develop an alternative pricing system designed for forest managers who manage for multiple forest values.

\section{Diverse motivations for pursuing community forestry}

This research echoes current community-based natural resource management and community forest discourse with respect to community motivations for local control over local resources for local benefits. This remains the mantra of community forestry in BC. Local benefits usually mean economic returns or environmental conservation, and in the case of aboriginal peoples, cultural autonomy (Agrawal and Gibson 1999, Pinkerton 1999). With respect to British Columbia, the impe- tus for control comes from 100 years of state and industry control over forest lands and policy and the perceived neglect of the interests of First Nations, labour, forest-dependant communities, and the environment (Bullock and Hanna 2008). Various elements of these concerns were reflected across the case studies. What stood out in this research was the common desire of communities to be self-reliant and self-directed, as well as a perceived need to be proactive rather than always responding to the plans of industry and government. Another common sentiment was that if any logging must happen within or near communities it should be done or controlled by the affected community primarily for local benefit.

However, local development pressure was also an impetus for increased local control in land use decision-making. Environmental degradation and resource depletion, increasing and excessive land taxes and housing values, and changes to community culture, lifestyle, and population growth were all concerns that residents linked to increasing development and forest management. Development pressure presents a challenge for communities seeking to control land use decisionmaking over areas beyond their legal jurisdiction. As seen here this was especially true for the unorganized island communities. Especially on private property, road-building and logging increases the chances of future subdivision and lot sales. The Denman and Cortes Island cases point to a need for proactive management regulations/policies for private forest land in BC. Creating strong sustainable forestry bylaws may be a sufficient alternative for communities that do not necessarily want to pursue community forestry for its fullest economic potential or where economic viability is questionable.

Communities must be sure of their intentions and they must be sure that community forestry is really the appropriate route to achieving local goals. The provincial government and MOFR view community forests as one way to stimulate local economies and, in certain settings, to mitigate conflictnot to create protected areas. Communities with motivations that do not fit these intentions are less likely to succeed under the current provincial framework. At the same time policymakers and forest managers need to recognize that some communities are transitioning from resource to service economies with increasing populations and shifting values.

In the above cases community forestry began as a response to local environmental and economic problems related to forest management. Each community was reacting to what were believed to be negative changes, introduced by "outside" forces. However, the driving forces varied. The main difference was between communities where forests were important to lifestyle and tourism (Denman Island, Cortes Island) and where forests were important from the standpoint of the traditional forest community-industry compact (Malcolm Island and Creston). The return of large-scale industrial harvesting operations after years of inactivity sparked serious protests on Cortes and Denman Islands; one Malcolm Island participant expressed concern that industry would again return once the forests there had regenerated. In Creston, the return of logging to Arrow Creek, even by a "green" community-based operation, was met with great protest from water groups and residents. Nonetheless, in each case community control was the primary motivation whether it was to have increased control over residential, commercial, or industrial development in terms of local forest resources and 
economies. As each community sought to implement ecosystem-based forest management principles, they shared common values, though with varying degrees of emphasis. This final point illustrates the diverse values to be represented in forest management at the community level and, indeed, throughout the province.

\section{Lessons and Recommendations}

This section distils the best lessons learned through the case studies and literature review in order to make specific recommendations for practice. Given current provincial policy, it appears that the onus is on communities to prove that they are "ready" for involvement in forest management, and can continue as viable local resource management institutions. Accordingly, the following list provides practical suggestions to community forest organizations, stakeholder groups, and policy-makers for improving success throughout the process:

- Define goals and objectives at the start. These may evolve, but a definite starting point is necessary. In doing this, it is very important that residents work to determine what they want to do, but also why. In other words, there is a need to determine the true motivations driving pursuit of community forestry. It may be that there are other mechanisms to appropriately address some of the issues of community concern.

- It is essential to formalize the community forest group early on. Local movements typically start with a core group of supporters or an organizing committee. In the above cases each community forest organization was born of some other local forestry committee. Irrespective of the model selected (corporation, co-operative, society, partnership), developing some semblance of formal governance early on gives everyone something to rally around. It is an inward and outward sign of legitimacy and progress.

- First Nations and non-aboriginal groups should foster good working relations with one another even if they do not plan to work together. Having explicit knowledge that other community groups support your efforts rather than oppose them can facilitate senior government cooperation. Document all agreements and the resolution of all conflicts, no matter how small or trivial they might seem, and be able to demonstrate these to senior governments.

- Maintain ongoing communication with politicians and bureaucrats at all levels of government. The Creston example illustrates that "the lobbying never stops." You may not win government support right away, but experience shows that everyone's thinking-including that of politicians and industry representatives - can evolve over time. Be persistent.

- Develop creative ways of engaging the public to avoid unproductive yelling matches at the local town hall. It is important to discuss and to try and work through all conflicts within the community; however, there is a need to maximize the productivity of volunteer energy. It is equally as important for novice and established organizations to maintain linkages with the community. Established organizations must not become complacent about their image in the community.

- Explore partnership opportunities with public and private institutions. Resource and information needs can sometimes be addressed through exchange with partner organizations. Prioritize resource and information needs early on and work with partner organizations and associations (e.g., BCCFA) to identify common information needs and facilitate data-sharing. Seek university research support to develop information. These are effective ways to share often limited resources (e.g., expertise, technology, office space, research funding) and inject new ideas and energy.

- Community forest groups often work with hand-drawn maps and illustrations as a way to create or customize existing information. Information development is a significant part of the planning process that can facilitate implementation. Where possible, communities should try to develop their own information on their forests and community, and develop quality maps. The case studies show that the process of developing maps and plans, albeit challenging, can be empowering. Possessing specialized information on the local setting improves the organization's strategic negotiation position with government and industry, and adds legitimacy to the initiative by bolstering resources. It also provides a universal tool and data display medium to share with others, especially residents, and can be a source of pride and symbol of progress. The process of developing maps can advance sound planning by further defining goals and objectives through discussion. But clear priorities for information needs are essential; refine existing data where possible and maintain a focus on data quality and efficiency in collection.

- Seek professional consultation. RPFs, lawyers, planners, accountants, and consultants will play an important role in all successful community forests. Financial resources will often dictate how soon these individuals can be brought into the process. In some cases local volunteers possess necessary expertise and accreditation, while in other cases community organizations will have to fundraise or secure loans. Professional consultation will add a degree of legitimacy to local initiatives and provide someone who "speaks the same language" as government and industry representatives. If possible, hire the same consultants that work with industry and government forestry agencies.

The above recommendations are not intended to be a generic master list of success factors for all community forests initiatives. Indeed it is unlikely that all such conditions can be met in every setting, and the absence of any one, or more, does not necessarily preclude success. What works in some communities may fail in others. Certainly, the need to build community awareness as a prerequisite for building local support and the need to demonstrate progress to those within the community and beyond are common threads that link these lessons and community experiences. In this way these recommendations support the greater movement for acceptance of community forestry as a valuable mechanism for community involvement in forest management.

\section{Conclusions}

These 4 case studies show how key events and actors influenced the unfolding of community forest initiatives in different places. There are hundreds more across $\mathrm{BC}$ whose efforts have contributed directly and indirectly to the development of community forest policy and operational community forests. The critical challenges outlined here mark key community and provincial policy issues that need to be addressed. The analysis also illustrates background motivations that are of vital importance but not necessarily congruent with the current vision for community forestry, although this is indeed still 
being shaped at this formative stage. The reconciliation of divergent values and perspectives among citizens, politicians, and foresters is ongoing and will have much to do with refining the community forest concept as forest management continues to become more "inclusive and open" (McGurk et al. 2006). There is a delicate and essential balance to be achieved in government policy-and decision-making that is directed by the desires of the citizenry and informed by the expertise of foresters and other forestry professionals. However, another common thread is that institutional constraints have limited the potential of community forestry, and it is at the provincial level that advocacy for change will have to be focused.

These case studies also illustrate transition in the BC forest industry and the evolution of resource community values, but in many respects the experience and lessons noted here are applicable to other jurisdictions. Though resource development continues to play a major role in local and provincial economies, the character of resource communities has increasingly changed from hinterland to homeland. The forest-community relationship is evolving and forest managers face new sets of challenges in managing BC's forests. While community forestry in BC, and elsewhere in Canada, faces important implementation challenges, it is a concept that holds great promise for local economies and for realizing new approaches to forest resource management.

\section{Acknowledgements}

The authors greatly appreciate the time and knowledge provided by community members who participated in the research project. Support for this work has been provided by the Social Sciences and Humanities Research Council and inkind support has been generously provided by Western Forest Products. We are grateful to Pam Schaus, Cartographer in the Department of Geography and Environmental Studies at Wilfrid Laurier University, for providing her technical expertise. Finally, we thank the 2 anonymous reviewers for their time and very helpful suggestions.

\section{References}

Agrawal, A. and C. Gibson. 1999. Enchantment and disenchantment: The role of community in natural resource conservation. World Dev. 27(4): 629-649.

Allan, K. and D. Frank. 1994. Community forests in British Columbia: Models that work. For. Chron. 70(6): 721-724.

Ambus, L., D. Davis-Case and S. Tyler. 2007. Big expectations for small forest tenures in British Columbia. BC J. of Ecosystems and Mgt. 8(2): 46-57. Available at http://www.forrex.org/

publications/jem/ISS41/vol8_no2_art4.pdf

Beattie, D. (ed.) 1997. Industrial forestry within a fragile island against its largest landowner. The Voice, October 1997: 4-11.

Beckley, T. 1998. Moving toward consensus-based forest management: A comparison of industrial, co-managed, community and small private forests in Canada. For. Chron. 74(5): 736-744.

Berkes, F. and C. Folke. 1998. Linking social and ecological systems for resilience and sustainability. In F. Berkes, C. Folke and J. Colding (eds.). Linking social and ecological systems: Management practices and social mechanisms for building resilience. pp. 1-26. Cambridge University Press, New York.

Bradshaw, B. 2003. Questioning the credibility and capacity of community-based resource management. Can. Geog. 47(2): 137-150.

Bradshaw, B. 2007. On definitions of "success" and contingencies affecting success in community forestry: A response to Reed and McIlveen (2006) and Pagdee et al. (2006). Soc. and Nat. Res. 20(8): $751-753$.
Broughton Archipelago Stewardship Society. 2004. Stewardship News November 2004. Broughton Archipelago Stewardship Society, Sointula, BC.

Bullock, R. 2007. Two sides of the forest. J. of Soil and Wat. Con. 62(1): 12A-15A.

Bullock, R and K. Hanna. 2008. Community forestry: Mitigating or creating conflict in British Columbia? Soc. and Nat. Res. 21(1): 77-85. Clapp, R.A. 1998. The resource cycle in forestry and fishing. Can. Geog. 42(2): 129-144.

[CES] Cortes Ecoforestry Society. no date. Summary. Cortes Island: Cortes Ecoforestry Society.

Daniels, S. E. and G. B. Walker. 1996. Collaborative learning: Improving public deliberation in ecosystem-based management. Env. Imp. Ass. Rev. 16(2): 71-102.

[DCFC] Denman Community Forest Co-operative. 2001. Denman Community Forest Co-operative homepage. Available at http://www.denmanis.bc.ca/forestry.htm [Accessed March 1, 2005]. Duinker, P.N., P. Matakala, F. Chege and L. Bouthillier. 1994. Community forestry in Canada: An overview. For. Chron. 70(6): 711-720.

Duinker, P.N., P. Matakala and D. Zhang. 1991. Community forestry and its implications for Northern Ontario. For. Chron. 67(2): 131-135.

Dunster, J. 1994. Managing forests for forest communities: A new way to do forestry. Inter. J. of Ecoforestry 10(1): 43-47.

Gunter, J. (ed.). 2004. The community forestry guidebook: Tools and techniques for communities in British Columbia. FORREXForest Research Extension Partnership and British Columbia Community Forest Association: Kamloops and Kaslo. FORREX Series Report No. 15. Available at http://www.forrex.org/publications/forrexseries/fs15.pdf.

Hanna, K.S. 2007. Implementation in a complex setting: Integrated environmental planning in the Fraser River estuary. In K.S. Hanna and D.S. Slocombe (eds.) Integrated Resource and Environmental Management: Concepts and Practice. pp. 119-136. Oxford University Press, Oxford. 288 p.

Hjern, B., K. Hanf and D. Porter. 1978. Local networks of manpower training in the federal republic of Germany and Sweden. In $\mathrm{F}$. Scharp and K. Hanf (eds.). Interorganizational policy making: Limits to coordination and central control. pp. 303-344. Sage Publications Inc., London.

Holling, C.S. 1995. What barriers? What bridges? In L. Gunderson, C.S. Holling and S. Light (eds.). Barriers and bridges to the renewal of ecosystems and institutions. pp. 3-36. Columbia University Press, New York.

Keen, M., Brown, V. A. and R. Dyball (eds.). 2005. Social learning in environmental management: towards a sustainable future. Earthscan, London; Sterling, VA. 288 p.

Kimmins, J.P. 1992. Balancing act: Environmental issues in forestry. UBC Press, Vancouver. $244 \mathrm{p}$.

[Klahoose, CES and Weyerhaeuser] Klahoose First Nation, Cortes Ecoforestry Society, and Weyerhaeuser Company Limited. 2000. The Cortes initiative: A proposal to the Government of British Columbia.

Matakala, P.W. and P. Duinker. 1993. Community forestry as a forest-land management option in Ontario. In D. Bruce and M. Whitla (eds.). Forest dependent communities: Challenges and opportunities. Rural and Small Town Research and Studies Program, Mount Allison University, Sackville, NB.

McCarthy, J. 2006. Neoliberalism and the politics of alternatives: Community forestry in British Columbia and the United States. Annals of the Association of American Geographers 96(1): 84-104. McGurk, B., A.J. Sinclair and A. Diduck. 2006. An Assessment of Stakeholder Advisory Committees in Forest Management: Case Studies from Manitoba, Canada. Soc. and Nat. Res. 19(9): 809-826. M'Gonigle, M. 1996. Living communities in a living forest: Towards an ecosystem-based structure of local tenure and management. Discussion paper, Victoria, BC. Available at http://www.polisproject. 
org/polis2/Discussion\%20Papers/D96-3b-Living\%20Communities.pdf.

Olsson, P., C. Folke and F. Berkes. 2004. Adaptive comanagement for building resilience in social-ecological systems. Env. Mgt. 34(1): 75-90.

Parfitt, B. and K. Garner. 2004. Axing the Forest Service: How British Columbians are losing their eyes and ears in the forest. Sierra Club of Canada, BC Chapter, Victoria, BC.

Pinkerton, E. 1999. Factors in overcoming barriers to implementing co-management in British Columbia salmon fisheries. Con. Ecol. (3)2. Quaghebeur, K., J. Masschelein and H.H. Nguyen. 2004. Paradox of participation: Giving or taking part? J. Community Appl. Soc. 14(3): 154-165.

Reed, M.G and K. McIlveen. 2006. Toward a pluralistic civic science? Assessing community forestry. Soc. and Nat. Res. 19: 591-607. Reed, M.G and K. McIlveen. 2007. Other voices from the neighborhood: Reconsidering success in community forestry - A response to Bradshaw's commentary paper: On definitions of "success" and contingencies affecting success in community forestry. Soc. and Nat. Res. 20(8): 755-758.

[RDMW] Regional District of Mount Waddington. 2005. Bylaw no. 708 Malcolm Island official community plan: 27. Regional District of Mount Waddington, Port McNeill, BC.
Robinson, D., M. Robson and R. Rollins. 2001. Towards increased citizen influence in Canadian forest management. Environments 29(2): 21-41.

Schusler, T. M., D.J. Decker and M.J. Pfeffer. 2003. Social learning for collaborative natural resource management. Soc. and Nat. Res. 16(4): 309-326.

Silva Forest Foundation. 1996. Initial report on methodology and results of Cortes Island ecosystem-based plan. Silva Forest Foundation, Slocan Park, BC.

Slocombe, D.S. 1993. Implementing ecosystem-based management: Development of theory, practice, and research for planning and managing a region. Bioscience 43(9): 612-622.

Statistics Canada. 2001. Community profiles. Available from http://www12.statcan.ca/english/profil01/PlaceSearchForm1.cfm [Accessed January 31, 2005].

Teitelbaum, S., T. Beckley and S. Nadeau. 2006. A national portrait of community forestry on public land in Canada. For. Chron. 82(3): 416-428.

Yin, R. 2003. Case study research: Design and methods, $3^{\text {rd }}$ ed. Sage Publications Inc., Thousand Oaks, CA. 181 p. 